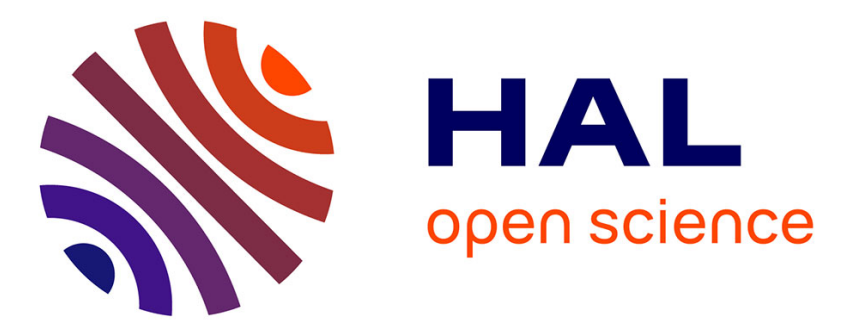

\title{
A new cheyletid mite Metacheyletia ngaii n. sp. (Acariformes: Cheyletidae) from quills of Corythaixoides leucogaster (Musophagidae) from Tanzania
}

\author{
A.V. Bochkov, M. Skoracki
}

\section{- To cite this version:}

A.V. Bochkov, M. Skoracki. A new cheyletid mite Metacheyletia ngaii n. sp. (Acariformes: Cheyletidae) from quills of Corythaixoides leucogaster (Musophagidae) from Tanzania. Acarologia, 2011, 51 (1), pp.93-97. 10.1051/acarologia/20111996 . hal-01599952

\section{HAL Id: hal-01599952 \\ https://hal.science/hal-01599952}

Submitted on 2 Oct 2017

HAL is a multi-disciplinary open access archive for the deposit and dissemination of scientific research documents, whether they are published or not. The documents may come from teaching and research institutions in France or abroad, or from public or private research centers.
L'archive ouverte pluridisciplinaire HAL, est destinée au dépôt et à la diffusion de documents scientifiques de niveau recherche, publiés ou non, émanant des établissements d'enseignement et de recherche français ou étrangers, des laboratoires publics ou privés.

\section{(ㅇ)(1) $\$$}

Distributed under a Creative Commons Attribution - NonCommercial - NoDerivatives| 4.0 


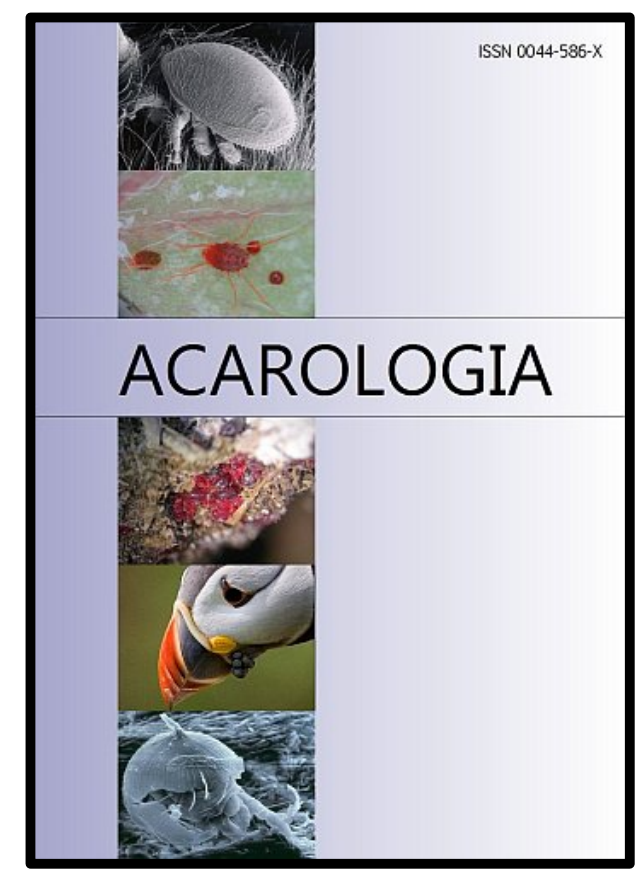

\section{ACAROLOGIA}

A quarterly journal of acarology, since 1959

Publishing on all aspects of the Acari

All information:

http://www1.montpellier.inra.fr/CBGP/acarologia/ acarologia@supagro.inra.fr

\section{OPEN ACCESS}

\section{Acarologia is proudly non-profit, with no page charges and free open access}

Please help us maintain this system by encouraging your institutes to subscribe to the print version of the journal and by sending us your high quality research on the Acari.

Subscriptions: Year 2017 (Volume 57): $380 €$ http://www1.montpellier.inra.fr/CBGP/acarologia/subscribe.php

Previous volumes (2010-2015): $250 € /$ year (4 issues)

Acarologia, CBGP, CS 30016, 34988 MONTFERRIER-sur-LEZ Cedex, France

The digitalization of Acarologia papers prior to 2000 was supported by Agropolis Fondation under the reference ID 1500-024 through the « Investissements d'avenir » programme

(Labex Agro: ANR-10-LABX-0001-01)
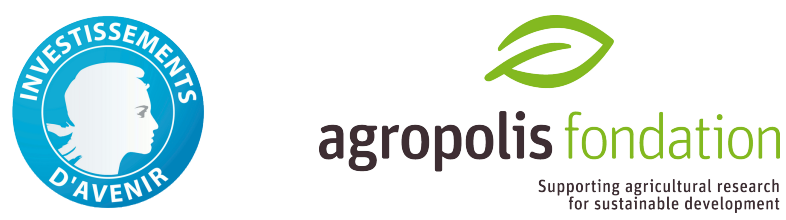

Acarologia is under free license and distributed under the terms of the

Creative Commons-BY-NC-ND which permits unrestricted non-commercial use, distribution, and reproduction in any medium, provided the original author and source are credited. 


\title{
A NEW CHEYLETID MITE METACHEYLETIA NGAII N. SP. (ACARIFORMES: CHEYLETIDAE) FROM QUILLS OF CORYTHAIXOIDES LEUCOGASTER (MUSOPHAGIDAE) FROM TANZANIA
}

\author{
Andre V. BOCHKOV ${ }^{1,2}$ and Maciej SKORACKI ${ }^{3}$ \\ (Received 10 December 2010; accepted 15 February 2011; published online 30 March 2011) \\ ${ }^{1}$ Zoological Institute, Russian Academy of Sciences, Universitetskaya emb. 1, 199034 St. Petersburg, Russia. andrevbochkov@gmail.com \\ ${ }^{2}$ Museum of Zoology, University of Michigan, 1109 Geddes Ave., Ann Arbor, Michigan 48109, USA \\ ${ }^{3}$ Department of Animal Morphology, Adam Mickiewicz University, Faculty of Biology, Umultowska 89, 61-614 Poznan, Poland \\ skoracki@amu.edu.pl
}

ABSTRACT - Metacheyletia ngaii n. sp. (Acariformes: Cheyletidae) is described from quills of Corythaixoides leucogaster (Rüppell, 1842) (Cuculiformes: Musophagidae) from Tanzania.

KEYWORDS - Acari; Cheyletidae; Metacheyletia; systematics; feather quills; Corythaixoides leucogaster

\section{INTRODUCTION}

The genus Metacheyletia Fain, 1972 (Acariformes: Cheyletidae) is a single genus of the tribe Metacheyletiini (Bochkov and Fain, 2001). Mites of this genus, currently including four species, live inside the feather quills. Three species are known from various parrots (Psittaciformes: Psittacidae), M. obesa Fain, 1972 from Psittacula krameri (Scopoli, 1769) from Africa (Fain, 1972, 1980), M. longisetosa Atyeo et al., 1984 from Amazona finschi (Sclater, 1864) from Mexico (Atyeo et al., 1984), M. amazonae Bochkov \& OConnor, 2003 from Amazona amazonica (Linnaeus, 1766) from Guyana (Bochkov and OConnor, 2003); one species, M. degenerata Fain \& Bochkov, 2003 was described from Serinus mozambicus (Muller, 1776) (Passeriformes: Fringillidae) from Tanzania (Fain and Bochkov, 2003).

Few data are known on biology of these mites, and suggestions concerning their mode of life are controversial. Atyeo et al. (1984) believed that these mites are predators because their movable cheliceral digits are too short to penetrate the quill wall, pierce the quill wall and reach live tissues of a host. Bochkov and Fain (2001) considered these mites parasitic based on morphological characters such as the short tarsi of legs I-III, the absence of legs IV, the short and nude eupathidia of the palpal tarsus and the relatively small sizes of the gnathosoma and suggested that Metacheyletia spp. use the orifices in quill walls which were made by adult syringophilids.

In this paper, we describe a new species of this genus from Corythaixoides leucogaster (Rüppell, 1842) (Cuculiformes: Musophagidae) from Tanzania. A key to females of all known species of the genus Metacheyletia is provided. 


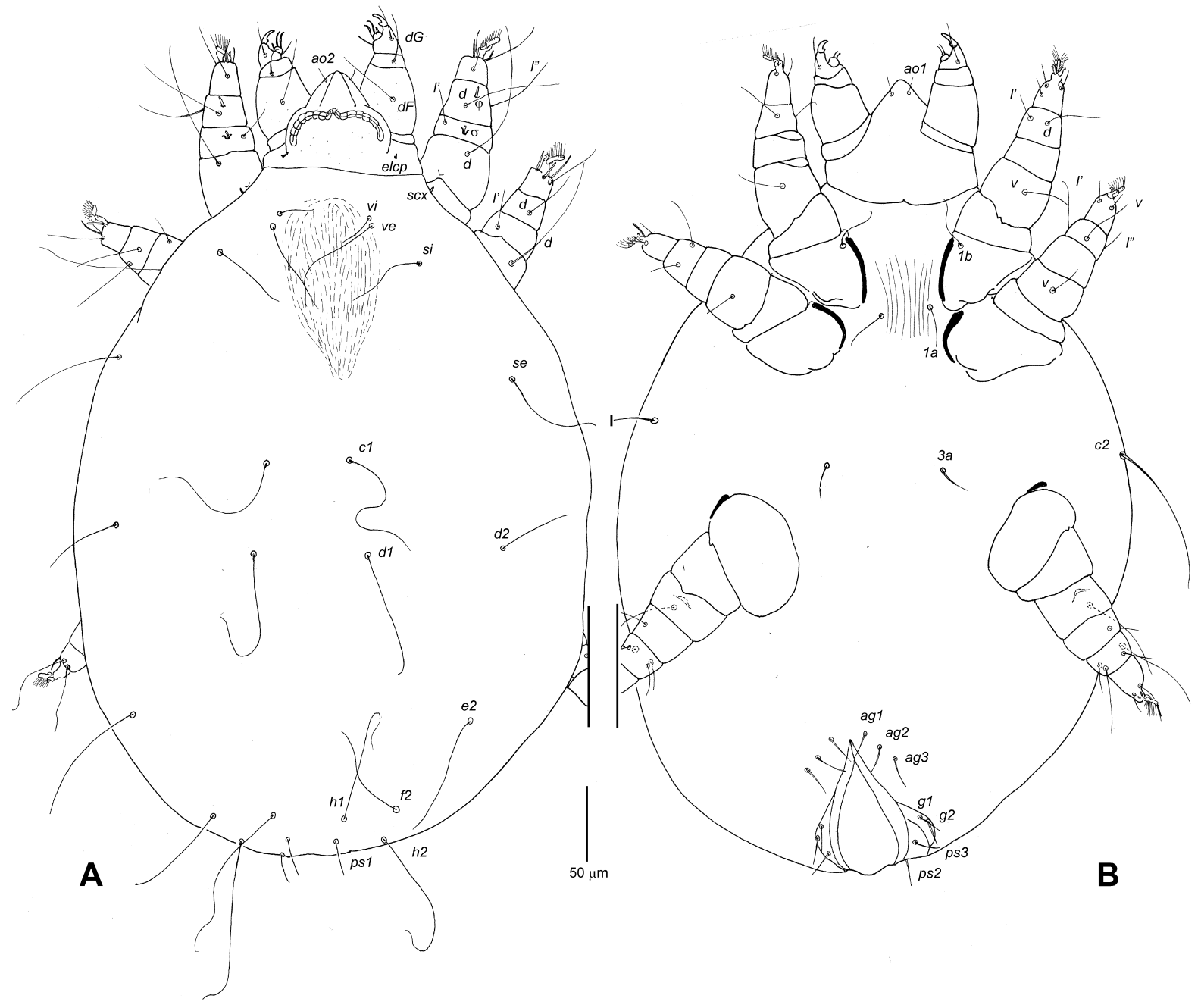

FIGURE 1: Metacheyletia ngaii sp. nov., holotype female. A - Dorsal view. B - Ventral view.

\section{MATERIALS AND METHODS}

Mites were mounted in Hoyer's medium. Drawings were made with a phase contrast Leica microscope with a camera lucida and DIC optics. In the descriptions below, the idiosomal setation follows Grandjean (1939) as adapted for Prostigmata by Kethley (1990). The nomenclature for leg setae follows that of Grandjean (1944). In predaceous cheyletids of the above listed genera, species diagnostic is mostly based on females, because males are rarely recorded and known just for a few species. All measurements are in micrometres $(\mu \mathrm{m})$. The scientific names and classification of birds follow Clements (2007).

\section{FAMiLy CHEYLETIDAE}

\section{Metacheyletia ngaii n. sp. (Figures 1 and 2)}

Description - Female (holotype) - Gnathosoma 90 long (90 in 1 paratype) and 115 wide (120). Peritremes arch-like, each peritremal branch with 7-8 segments. Palpal femur 40 long (40) and 37 wide (35). Palpal claw with 1 basal tooth. Palpal setation: palpal femur - $d F$; palpal genu $-d G$; palpal tibia $d T i, l^{\prime} T i, l^{\prime \prime} T i$; palpal tarsus - smooth eupathidia amc, sul, $u l^{\prime}, u l^{\prime \prime}$, and solenidion $\omega 1$. Subcapitular setae $n$ absent, adoral setae $a 01, a 02$, and subcoxal setae elcp present. Idiosoma 495 long (585) and 355 wide (415), 

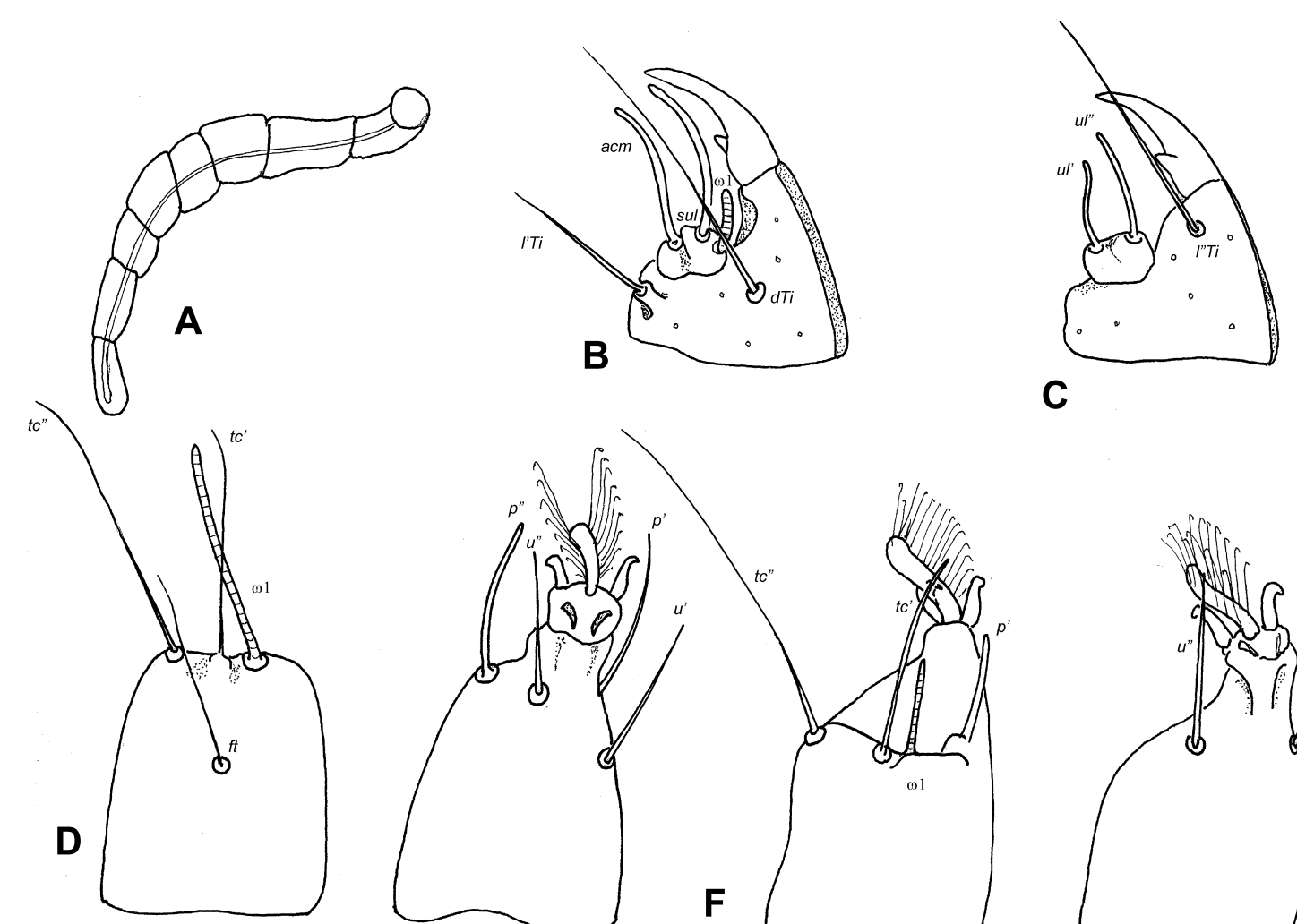

E

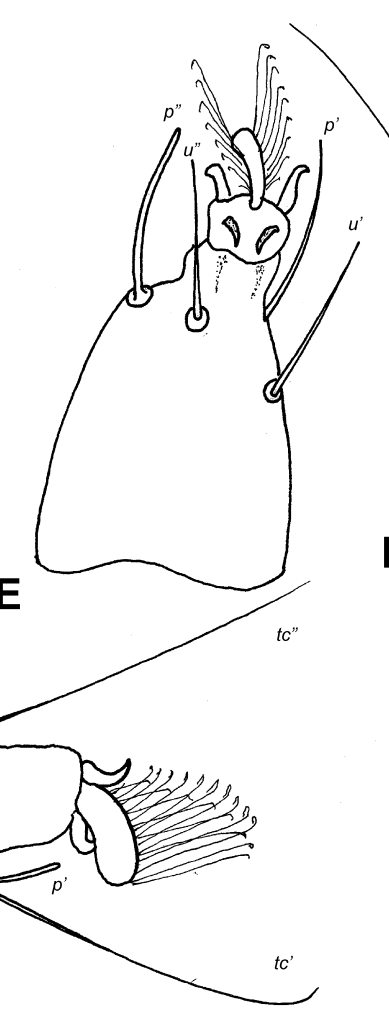

H

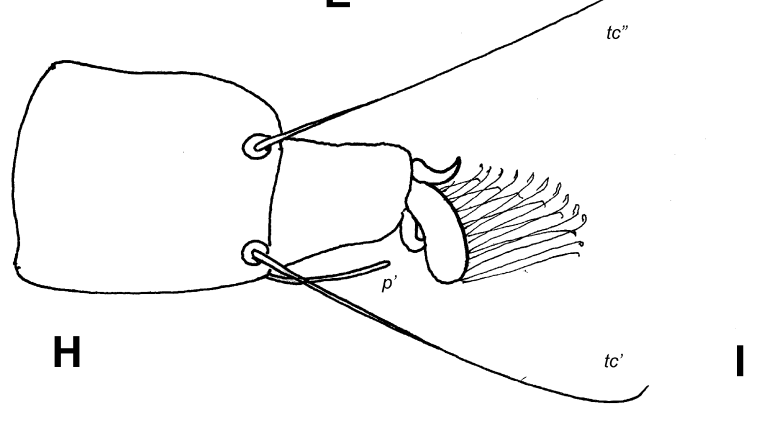

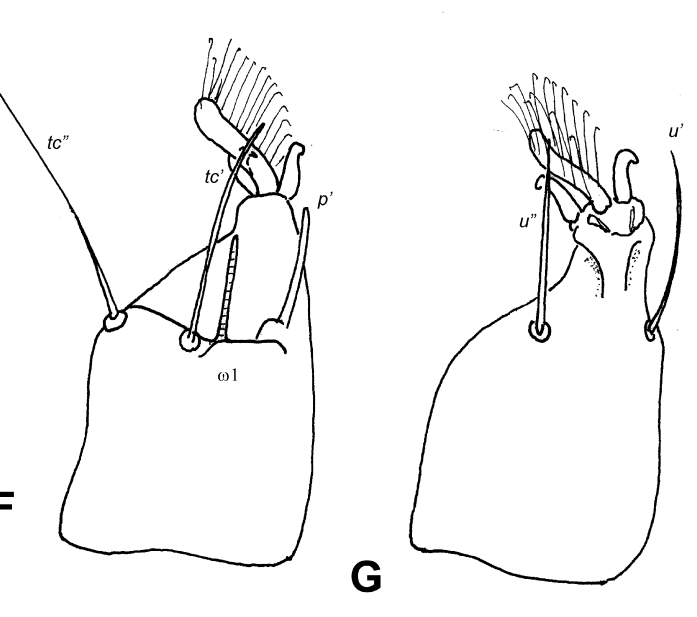
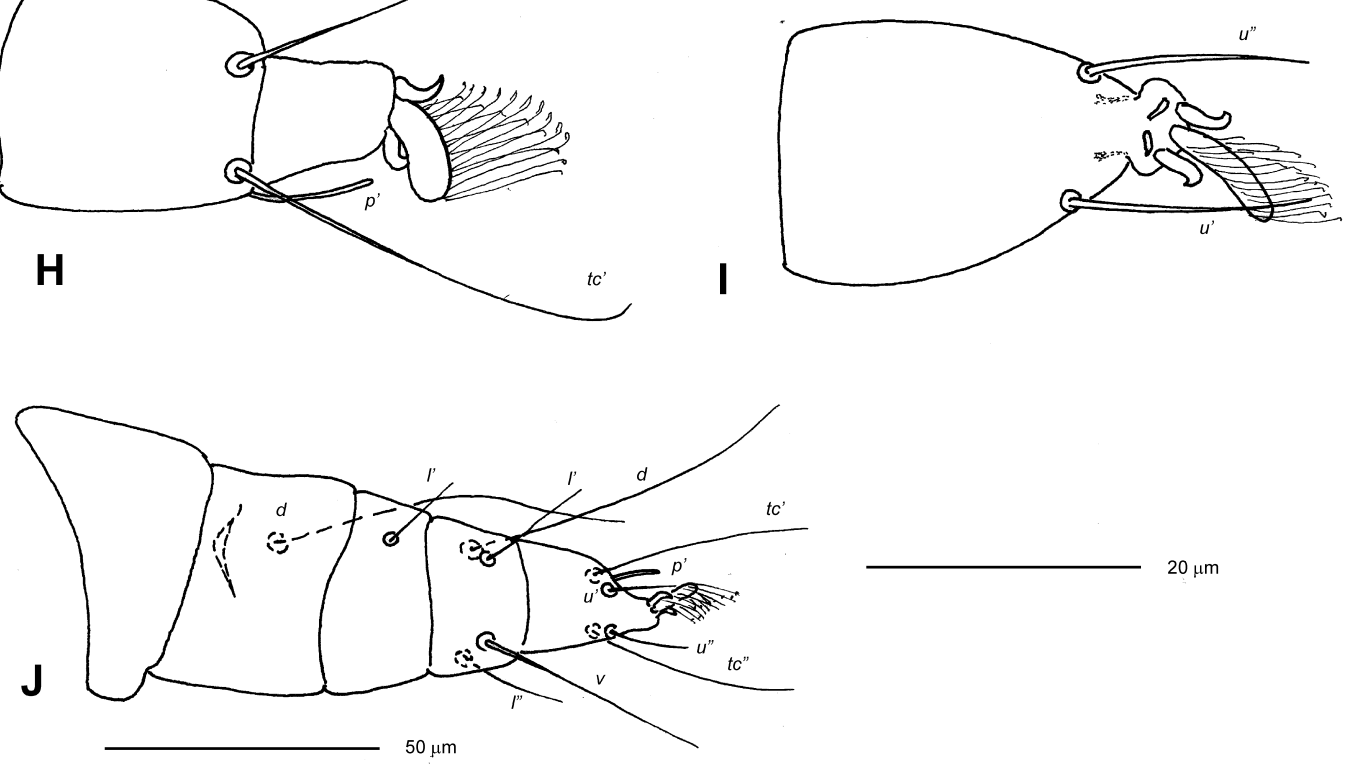

$20 \mu \mathrm{m}$

FIGURE 2: Metacheyletia ngaii sp. nov., details of holotype female. A - Peritremal branch. B - Palpal tibiotarsus in dorsal view. C - Same in ventral view. D - Tarsus I in dorsal view. E - Same in ventral view. F - Tarsus II in dorsal view. G - Same in ventral view. H Tarsus III in dorsal view. I - Same in ventral view. J - Leg III in ventral view. Scale bars: A-I $=20 \mu \mathrm{m}$; J = 50 $\mu \mathrm{m}$. 
ovoid. Propodonotal shield indistinct. No cupules observed. All idiosomal setae smooth filiform. Setae vi 2 times shorter than ve; setae si and $d 2$ 1.41.5 times shorter than $s e$ and $e 2 ; c 1$ and $d 1$ about 2 times longer than $d 2$; setae $c 1$ longer than distance between setal bases $c 1$ and $d 1$; setae $h 1$ and $h 2$ subequal. Three pairs of pseudogenital (ps1-ps3), 2 pairs of genital ( $g 1$ and $g 2$ ), and 3 pairs of aggenital (ag1ag3) setae present. Lengths of setae: vi 30 (35), ve 65 (70), si 50, se 70 (70), c1 130, c2 120 (125), d1120 (115), d2 50 (65), e2 80 (75), f2 65 (75), h1 120 (115), h2 115 (120), ps1-ps3 23-25, g1 and g2 24-25, ag1-ag3 2327, 1a 35 (35), $1 b 45$ (55), $3 a 35$ (35). Setae $4 a$ absent. Legs IV completely absent. Leg I-IV setation: I tarsus with 7 setae $\left(f t, t c^{\prime}, t c^{\prime \prime}, p^{\prime}, p^{\prime \prime}, u^{\prime}, u^{\prime \prime}\right)+$ solenidion $\omega 1$, tibia with 4 setae $\left(d, l^{\prime}, l^{\prime \prime}, v\right)+$ solenidion $\varphi$, genu with 1 seta $\left(l^{\prime}\right)+$ solenidion $\sigma$, femur with 2 setae $(d F$ and $v F)$, trochanter without setae, coxal field with 1 seta (1b); II - tarsus with 5 setae $\left(t c^{\prime}, t c^{\prime \prime}\right.$, $\left.p^{\prime}, u^{\prime}, u^{\prime \prime}\right)+$ solenidion $\omega 1$, tibia with 4 setae $\left(d, l^{\prime}\right.$, $\left.l^{\prime \prime}, v\right)$, genu with 1 seta $\left(l^{\prime}\right)$, femur with 2 setae $(d F$ and $v F$ ), trochanter and coxal field without setae; III - tarsus with 5 setae $\left(t c^{\prime}, t c^{\prime \prime}, p^{\prime}, u^{\prime}, u^{\prime \prime}\right)$, tibia with 4 setae $\left(d, l^{\prime}, l^{\prime \prime}, v\right)$, genu with 1 seta $\left(l^{\prime}\right)$, femur with 1 seta $(d F)$, trochanter and coxal field without setae.

Male - Unknown.

Type Material - Holotype female and female paratype from Corythaixoides leucogaster (Rüppell, 1842) (Cuculiformes: Musophagidae), Tanzania: Tanganyika, 23 March 1960, coll. unknown.

Type deposition - All material is deposited in the Zoological Institute of the Russian Academy of Sciences, St. Petersburg, Russia.

Etymology - This new species is dedicated to the Maasai God - Ngai, the creator of everything.

Differential diagnosis. This new species is morphologically closest to $M$. degenerata. In females of both species, three pairs of aggenital setae are present and the propodonotal shield is indistinct. It differs from $M$. degenerata by the following features. In females of M. ngaii n. sp., setae vi are two times shorter than ve, setae $d 2$ are two times shorter than $d 1$, setae $h 1$ and $h 2$ are subequal, setae $c 1, d 1$, and $e 2$ are 130, 115-120, and 75-80 long, respectively. In females of $M$. degenerata, setae vi are 1.1-1.2 times shorter than $v e$, setae $d 1$ and $d 2$ are subequal, setae $h 1$ are about 1.3 times shorter than $h 2$, setae $c 1, d 1$, and $e 2$ are 65,60 , and 50 long, respectively.

Remarks - The genus Metacheyletia is, probably, initially associated with parrots, because its representatives inhabit these hosts in Africa and South America. Unfortunately these mites are unknown from Australia, and records of Metacheyletia spp. from the Australian parrots would be very desirable as an additional prove of this hypothesis. The two species of this genus from non-parrot hosts, $M$. degenerata and M. ngaii, are still known exclusively from central Africa and morphologically very close to each other. Parrots are widely distributed in central Africa and, therefore, we suggest that in this region, mites of the genus Metacheyletia shifted on a non-parrot host from a parrot with the following dispersion and speciation on birds of different nonparrot orders.

\section{Key to females of the genus Metacheyletia Fain, 1972}

1. Propodonotal shield weakly developed, but distinct; setae $a g 3$ absent (hosts - Psittacidae) ........ 3 - Propodonotal shield almost indistinct; setae ag3 present................................. 2

2. Setae vi 2 times shorter than $v e$; setae $d 22$ times shorter than $d 1$; setae $h 1$ and $h 2$ subequal. Setae $c 1, d 1$, and $e 2130,115-120$, and 75-80 long, respectively ............................ ngaii n. sp. - Setae vi 1.1-1.2 times shorter than ve; setae $d 1$ and $d 2$ subequal; setae $h 1$ about 1.3 times shorter than h2. Setae $c 1, d 1$, and $e 265,60$, and 50 long, respectively .......... M. degenerata Fain \& Bochkov, 2003

3. Remnants of legs IV absent ................ 4 — Remnants of legs IV present . M. obesa Fain, 1972

4. Peritremal branches with 7-8 segments each. Propodonotal shield devoid of setae; length ratios of dorsal idiosomal setae: h2:e2, f2 2:1 and h2:h1 1.2-1.6:1, length of setae $c 1$ subequal to distance between bases of setae $c l-d 1$. Setae $v e, s i, s e, c 1, e 2, f 2$

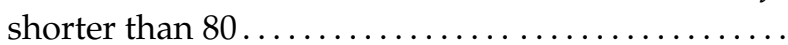
........... M. amazonae Bochkov \& OConnor, 2003 - Peritremal branches with 10-11 segments each. 
Propodonotal shield bearing setae $v i$ and $v e$, dorsal idiosomal setae $e 2, f 2, h 1$, and $h 2$ subequal in length, ratio between length of seta $c 1$ and distance between $c 1-d 1$ approximately $2.8: 1$. Setae $v e, s i$, se, $c 1, e 2, f 2$ longer than $100 \ldots \ldots \ldots \ldots \ldots \ldots \ldots$ ......... M. longisetosa Atyeo, Kethley \& Perez, 1984

\section{ACKNOWLEDGEMENTS}

This research was supported by a grant from the Russian Foundation for Basic Research (10-0400160-a) to AVB. In the frames of this project visit of AVB to the Adam Mickiewicz University, Poznan, Poland was supported by the special grant from administration of this university.

\section{REFERENCES}

Atyeo W.T., Kethley J.B., Perez T.M. 1984 - Paedomorphosis in Metacheyletia (Acari: Cheyletidae), with the description of a new species - J. Med. Ent., 21: 125131.

Bochkov A.V., Fain A. 2001 - Phylogeny and system of the Cheyletidae (Acari : Prostigmata) with special reference to their host-parasite associations - Bull. Inst. R. Sci. nat. Belg., 71: 5-36.

Fain A., Bochkov A.V., 2003 - A new species of the genus Metacheyletia Fain, 1972 (Acari: Cheyletidae) parasitizing Serinus mosambicus (Passeriformes: Fringillidae) in Central Africa - Int. J. Acarol., 29: 119-131. doi:10.1080/01647950308683648
Bochkov A.V., OConnor B.M. 2003 - New cheyletid mites (Acari, Cheyletidae) associated with birds Acta Parasitol., 46: 265-279.

Clements J.F. 2007 - The Clements checklist of birds of the world. 6th Edition - Ithaca, New York: Cornell University Press. pp. 864.

Fain A. 1972 - Notes sur les acariens des famines Cheyletidae et Harpyrhynchidae producteurs de gale chez les oiseaux ou les mammiferes - Acta Zool. Pathol. Antverp., 56: 37-60.

Fain A. 1980 - Notes on the genera Samsinakia Volgin, 1965 and Metacheyletia Fain, 1972 (Acari: Cheyletidae) - Int. J. Acarol., 6: 103-108. doi:10.1080/01647958008683204

Grandjean F. 1939 - Les segments postlarvaires de l'hysterosoma chez les oribates (Acariens) - Bull. Soc. Zool. Fr., 64: 273-284.

Grandjean F. 1944. Observations sur les acariens de la famille des Stigmaeidae - Arch. Sci. Phys. Natur., 26: 103-131.

Kethley J.B. 1990 - Acarina: Prostigmata (Actinedida) In: Dindal D.L (Ed). Soil Biology Guide. New York: Wiley. p. 667-756.

\section{COPYRIGHT}

(oc) EY-No-ND Bochkov and Skoracki. Acarologia is under free license. This open-access article is distributed under the terms of the Creative Commons-BY-NC-ND which permits unrestricted non-commercial use, distribution, and reproduction in any medium, provided the original author and source are credited. 